\title{
Genomic subpopulations within the species Pediococcus acidilactici detected by multilocus typing analysis: relationships between pediocin AcH/PA-1 producing and non-producing strains
}

\author{
Diego Mora, ${ }^{1}$ Maria Grazia Fortina, ${ }^{1}$ Carlo Parini,, ${ }^{1}$ Daniele Daffonchio ${ }^{2}$ \\ and Pier Luigi Manachini ${ }^{1}$
}

Dipartimento di Scienze e Tecnologie Alimentari e Microbiologiche, sezione Microbiologia Industriale ${ }^{1}$ and sezione Microbiologia Agraria, Alimentare e Ecologica², Università di Milano, via Celoria 2, 20133 Milano, Italy

\author{
Author for correspondence: Diego Mora. Tel: +39 223955849. Fax: +39 270630829. \\ e-mail:diego.mora@unimi.it
}

\begin{abstract}
A high degree of genetic polymorphism among $P$. acidilactici strains was highlighted by a multilocus typing approach analysing several housekeeping genes and by sampling the whole genome using random amplified polymorphic DNA (RAPD) fingerprint analysis performed by using a single primer pedA gene targeted in low-stringency amplification conditions. Restriction fragment length polymorphism of the $\mathrm{rpoC}, \mathrm{IdhD} / \mathrm{L}$ and $\mathrm{mle}$ genes, and a modified RAPD analysis, permitted the grouping of Pediococcus acidilactici strains in seven genotypes (I-VII). Genotypic results obtained by analysing housekeeping genes involved in the transcription/translation machinery and in primary metabolism were supported by phylogenetic analysis based on the partial $16 \mathrm{~S}$ rDNA sequencing of a reference strain of each of the seven clusters obtained. Three of the seven genotypes detected showed relationships with pediocin AcH/PA-1 production and carbohydrate fermentation patterns: all pediocin-producing and sucrose-positive strains were grouped in genotype VII, melibiose-, sucrose- and raffinose-positive strains in genotype VI, and arabinose-positive strains in genotype $\mathrm{V}$.
\end{abstract}

Keywords: Pediococcus acidilactici, pediocin AcH/PA-1, multilocus typing, intraspecific genetic variability

\section{INTRODUCTION}

The importance of Pediococcus acidilactici strains in the food industry is related to their use as starter cultures in fermented meat and vegetable products. This species, like most other lactic acid bacteria (LAB), is involved in extending the shelf life and improving the hygienic quality of various fermented products, via the production of lactic acid and/or the secretion of antibacterial compounds like bacteriocins (Stiles, 1996). The activity of the bacteriocin $\mathrm{AcH} / \mathrm{PA}-1$, produced by some $P$. acidilactici strains, against a broad spectrum of Grampositive bacteria, including Listeria monocytogenes,

Abbreviations: $L A B$, lactic acid bacteria; RAPD, random amplified polymorphic DNA.

The GenBank accession numbers for the sequences determined in this work are given in Table 4.
Staphylococcus aureus, Clostridium perfringens and Clostridium botulinum, is well known (Bhunia et al., 1988, 1991; Motlagh et al., 1994; Okereke \& Montville, 1991; Pucci et al., 1988). Because of this important feature, $P$. acidilactici has been studied for its pediocin production and its possible utilization in biopreservation processes (Schoeman et al., 1999; Stiles, 1996). In the last few years several studies have been carried out to investigate the mode of action of pediocin $\mathrm{AcH} / \mathrm{PA}-1$ and to obtain its expression in other species of LAB more suitable than $P$. acidilactici for the preparation of fermented dairy products (Chen et al., 1997; Chikindas et al., 1995; Fimland et al., 1996; Horn et al., 1998; Miller et al., 1998; Motlagh et al., 1992).

Despite the commercial importance of $P$. acidilactici, few attempts have been made to investigate the genetic variability in this species and to understand the molecular relationship between pediocin producer and non- 
producer strains. $P$. acidilactici has actually been studied only in relation to the DNA G $+\mathrm{C}$ content, the level of DNA-DNA homology (Garvie, 1986), and the phylogenetic position by analysis of the sequence of the $16 \mathrm{~S}$ rRNA gene (Collins et al., 1990). Pediocin AcH/PA-1 producer strains have been studied using whole-genome restriction fragment length polymorphism (RFLP) analysis and by the determining the sequence of the plasmid which carries the pediocin operon (Luchansky et al., 1992; Marugg et al., 1992; Motlagh et al., 1994).

The use of different PCR-based techniques addresses the issue of investigating genetic variability, since many methods have been developed for typing DNAs at different levels. Random amplified polymorphic DNA (RAPD) (Welsh \& McClelland, 1990) may be used for typing the whole genome while RFLP analysis of PCR products is useful for the typing of discrete genes.

As recently noted by Maiden et al. (1998), the use of multiple loci is essential to achieve the resolution required for providing meaningful relationships among strains, since clones diversify as a consequence of mutational and recombinational events, whose rates are different at different genetic loci; strains might be typed incorrectly if only a single locus is examined.

The aim of this study was to investigate the molecular variability of $P$. acidilactici strains, including pediocin $\mathrm{AcH} / \mathrm{PA}-1$ producer and non-producer strains, obtained from culture collections and food samples. The molecular genetic characterization of the species $P$. acidilactici, including pediocin producer and non-producer strains, should expand the knowledge on their phylogeny, and should lead to a simple, rapid and reliable identification of strains which may be important in food biotechnology processes. Moreover, the understanding of the molecular relationship between pediocin producer and non-producer strains could help in the assessment of the natural spread of pediocin AcH/PA-1 to other strains of $P$. acidilactici. The issue of the spread of pediocin $\mathrm{AcH} / \mathrm{PA}-1$ is particularly interesting because, to our knowledge, only a few strains of $P$. acidilactici producing the pediocin have been isolated worldwide (Ray, 1996).

\section{METHODS}

Strains and laboratory media. The strains of LAB used in this work, their origin and some relevant characteristics are shown in Table 1. Strains were routinely maintained at $4^{\circ} \mathrm{C}$ after growth at $37^{\circ} \mathrm{C}$ for 12 or $24 \mathrm{~h}$ in MRS broth (Difco). For longer-term maintenance, stock cultures were stored in $20 \%$ $(\mathrm{v} / \mathrm{v})$ glycerol, $80 \%(\mathrm{v} / \mathrm{v})$ MRS at $-20^{\circ} \mathrm{C}$ and $-80{ }^{\circ} \mathrm{C}$. Carbohydrate fermentation was carried out using BSM medium containing chlorophenol red at a final concentration of $4 \%(\mathrm{w} / \mathrm{v})$ and the desired filter-sterilized carbohydrate at a final concentration of $0 \cdot 2 \%(\mathrm{w} / \mathrm{v})$, as described by de Mann et al. (1960).

DNA preparation. For the PCR reaction, $100 \mu \mathrm{l}$ of an overnight culture in MRS broth was added to $400 \mu \mathrm{l} 1 \times$ TE buffer (10 mM Tris/HCl, $1 \mathrm{mM} \quad \mathrm{Na}_{2}$ EDTA, pH 8) containing $0.45 \mathrm{mg}$ lysozyme $\mathrm{ml}^{-1}$ (Sigma). This suspension was incu- bated for $30 \mathrm{~min}$ at $37^{\circ} \mathrm{C}$ and then SDS and proteinase $\mathrm{K}$ (Sigma) were added at a final concentration of $0.6 \%(\mathrm{w} / \mathrm{v})$ and $7 \mathrm{U} \mathrm{ml}^{-1}$ respectively. After incubation for $30 \mathrm{~min}$, the solution was extracted with an equal volume of phenol saturated with $1 \times$ TE. The DNA was then precipitated by adding $0 \cdot 1$ vol. sodium acetate and 2 vols $95 \%$ ethanol. The DNA pellet was air-dried, dissolved in $50 \mu \mathrm{l}$ sterilized water (HPLC grade) and stored at $-20^{\circ} \mathrm{C}$.

Primer selection, PCR conditions and restriction analysis. The sequences of the primers and their description are shown in Table 2. Before the use of the primers in PCR experiments their sequences were checked in the EMBL prokaryotes database using the EBI sequence homology searches, FASTA (Pearson \& Lipman, 1988; Pearson, 1990), to ensure that no significant matches with other genes were present. The amplifications of the $16 \mathrm{~S} \mathrm{rDNA}$ and the $r p o C$ (rpoCf), $l d h L$ (ldhLf), ldhD (ldhDf) and mle (mlef) fragments were carried out in a volume of $100 \mu \mathrm{l}$ containing: $3 \mu \mathrm{l}$ bacterial DNA solution obtained as above; $0 \cdot 1$ vol. $10 \times$ reaction buffer (Amersham Pharmacia Biotech); $200 \mu \mathrm{M}$ of each dNTP; $2.5 \mathrm{mM} \mathrm{MgCl} 2 ; 1 \mu \mathrm{M}$ each primer (Amersham Pharmacia Biotech); and $0.02 \mathrm{U}$ Taq polymerase $\mu \mathrm{l}^{-1}$ (Amersham Pharmacia Biotech). The temperature profile used consisted of the following: primary DNA denaturation step at $94^{\circ} \mathrm{C}$ for $2 \mathrm{~min}$ followed by 5 cycles of $45 \mathrm{~s}$ at $94^{\circ} \mathrm{C}, 45 \mathrm{~s}$ at $50^{\circ} \mathrm{C}$ and $1 \mathrm{~min}$ at $72{ }^{\circ} \mathrm{C} ; 30$ additional cycles were carried out increasing the annealing temperature to $55^{\circ} \mathrm{C}$. The amplifications of $l d h D f$ and mlef were carried out using the reaction mixture described above and the following temperature profile: primary DNA denaturation step at $94^{\circ} \mathrm{C}$ for $2 \mathrm{~min}$ followed by 35 cycles of $45 \mathrm{~s}$ at $94^{\circ} \mathrm{C}, 45 \mathrm{~s}$ at $60^{\circ} \mathrm{C}$ and $45 \mathrm{~s}$ at $72^{\circ} \mathrm{C}$. The amplification of the ped $A$, pedB, pedC and pedD genes was carried out using primers and experimental conditions as previously described (Mora et al., 1998).

The RAPD experiments with pedAF primer were performed in $25 \mu$ final volume using the following temperature profile with a modified ramp at $50 \%$ : primary DNA denaturation step at $94{ }^{\circ} \mathrm{C}$ for 2 min followed by 5 cycles of $45 \mathrm{~s}$ at $94{ }^{\circ} \mathrm{C}, 45 \mathrm{~s}$ at $31^{\circ} \mathrm{C}$ and $2 \mathrm{~min}$ at $72{ }^{\circ} \mathrm{C} ; 30$ additional cycles were carried out increasing the annealing temperature to $40^{\circ} \mathrm{C}$.

For all the amplification cycles the final extension was continued for $7 \mathrm{~min}$ at $72{ }^{\circ} \mathrm{C}$. The reproducibility of RAPD patterns was tested by repeating the analysis three times on the same DNA template and also using DNA extracted at different times.

All amplification reactions were performed in a Gene Amp PCR System 2400 (Perkin-Elmer). Following amplification, $5 \mu \mathrm{l}$ product was electrophoresed at $5 \mathrm{~V} \mathrm{~cm}^{-1}(1.5 \%$ agarose gel, $0 \cdot 2 \mu$ g ethidium bromide $\mathrm{ml}^{-1}$ ) in TAE buffer.

Restriction digestion of the amplified fragments was carried out for $3 \mathrm{~h}$ at $37^{\circ} \mathrm{C}$ or at $65^{\circ} \mathrm{C}$ in $20 \mu \mathrm{l}$ reaction mixture containing $7 \mu \mathrm{l}$ of the PCR product solution, $2-4 \mu \mathrm{l}$ incubation buffer and 5-10 $\mathrm{U}$ of one of the following restriction enzymes: AluI, HaeIII, HhaI, HpaII, RsaI, TaqI, HindIII (Amersham Pharmacia Biotech). Restriction digests were subsequently analysed by agarose electrophoresis $(3 \%, \mathrm{w} / \mathrm{v}$, agarose gel, containing $0.2 \mu \mathrm{g}$ ethidium bromide $\mathrm{ml}^{-1}$, TAE buffer) or by polyacrylamide electrophoresis $(6 \%$, acrylamide: bisacrylamide, 29:1, w/w; TBE buffer). The gels were run at $5 \mathrm{~V} \mathrm{~cm}$ cm $^{-1}$ in the appropriate buffer, stained in a solution containing $0.5 \mu$ g ethidium bromide $\mathrm{ml}^{-1}$ and photographed in UV light.

$16 S$ rDNA cloning, sequence determination and phylogenetic analysis. After amplification, $16 \mathrm{~S}$ rDNA products were cloned 
Table 1. Tested strains, origin and relevant characteristics

Bacteriocin phenotype: $\mathrm{Bac}^{-}$, bacteriocin activity not detected; $\mathrm{Bac}^{+}$, bacteriocin activity detected. $\mathrm{R}$, immunity to pediocin AcH/PA-1; S, sensitivity to pediocin AcH/PA-1.

\begin{tabular}{|c|c|c|}
\hline Strain & $\begin{array}{l}\text { Bacteriocin } \\
\text { phenotype }\end{array}$ & Origin and relevant characteristics \\
\hline \multicolumn{3}{|c|}{ Pediococcus acidilactici } \\
\hline Pdi11* & $\mathrm{Bac}^{-} \mathrm{S}$ & MAAE; sour dough (Mora et al., 1998) \\
\hline $\mathrm{PG}^{*}$ & $\mathrm{Bac}^{-} \mathrm{S}$ & MAAE; sour dough (Mora et al., 1998) \\
\hline Psp2* & $\mathrm{Bac}^{+} \mathrm{R}$ & $\begin{array}{l}\text { MAAE; fermented Italian sausages; pediocin AcH/PA-1 } \\
\text { producer strain (Mora et al., 1998) }\end{array}$ \\
\hline $\mathrm{F} \dagger$ & $\mathrm{Bac}^{+} \mathrm{R}$ & $\begin{array}{l}\text { Fermented sausages (Ray, 1996); pediocin AcH/PA-1 } \\
\text { producer strain }\end{array}$ \\
\hline JD1-23‡ & $\mathrm{Bac}^{+} \mathrm{R}$ & $\begin{array}{l}\text { Commercial meat starter (Ray, 1996); pediocin JD } \\
\text { producer strain }\end{array}$ \\
\hline UL5 $\mathbb{S}$ & $\mathrm{Bac}^{+} \mathrm{R}$ & $\begin{array}{l}\text { Cheddar cheese (Daba et al., 1991); pediocin } 5 \text { producer } \\
\text { strain }\end{array}$ \\
\hline PAC1.0 $\|$ & $\mathrm{Bac}^{+} \mathrm{R}$ & Pediocin AcH/PA-1 producer strain \\
\hline PAC750F & $\mathrm{Bac}^{-} \mathrm{R}$ & $\begin{array}{l}\text { PAC1.0 cured of the plasmid carrying the pediocin } \\
\text { AcH/PA-1 operon (Mora et al., 1998) }\end{array}$ \\
\hline LMG $17674 * *$ & $\mathrm{Bac}^{-} \mathrm{S}$ & Chili bo (Leisner et al., 1999) \\
\hline LMG $17680^{* *}$ & $\mathrm{Bac}^{-} \mathrm{S}$ & Chili bo (Leisner et al., 1999) \\
\hline LMG $17687 * *$ & $\mathrm{Bac}^{-} \mathrm{S}$ & Chili bo (Leisner et al., 1999) \\
\hline LMG $17689 * *$ & $\mathrm{Bac}^{-} \mathrm{S}$ & Chili bo (Leisner et al., 1999) \\
\hline LMG $17692 * *$ & $\mathrm{Bac}^{-} \mathrm{S}$ & Chili bo (Leisner et al., 1999) \\
\hline DSMZ $20284^{\mathrm{T}}$ & $\mathrm{Bac}^{-} \mathrm{S}$ & Barley (Back \& Stackebrandt, 1978) \\
\hline DSMZ 20238 & $\mathrm{Bac}^{-} \mathrm{S}$ & Mash (Nakagawa \& Kithara, 1959) \\
\hline ATCC 8042 & $\mathrm{Bac}^{-} \mathrm{S}$ & Mash (Nakagawa \& Kithara, 1959) \\
\hline ATCC 12697 & $\mathrm{Bac}^{-} \mathrm{S}$ & Origin not known \\
\hline ATCC 25740 & $\mathrm{Bac}^{-} \mathrm{S}$ & Plants (Dellaglio et al., 1981) \\
\hline \multicolumn{3}{|c|}{ Lactobacillus sp. } \\
\hline NCK 537\| & - & Bacteriocin-sensitive test strain for the activity assay \\
\hline
\end{tabular}

*Strains kindly provided by Professor A. Galli Volonterio, Department of Food Science and Microbiology, Agricultural, Food and Ecological Microbiology section (MAAE), University of Milan, Italy.

† Strain kindly provided by Professor Bibek Ray, Department of Animal Science, Food Microbiology Laboratory, University of Wyoming, USA.

$\ddagger$ Strain kindly provided by Professor Bob Hutkins, Department of Food Science and Technology, University of Nebraska-Lincoln, Lincoln, USA.

\Strain kindly provided by Dr Eric Emond, Stela Research Centre, Department of Food Science and Nutrition, Laval University, Quebec, Canada.

\| Strains kindly provided by $\operatorname{Dr}$ T. R. Klaenhammer, Department of Food Science, College of Agriculture and Life Sciences, North Carolina State University, obtained by Dr G. Giraffa, Istituto Sperimentale Lattiero Caseario, Lodi, Italy.

I Strain kindly provided by Dr G. Giraffa, Istituto Sperimentale Lattiero Caseario, Lodi, Italy.

** Belgian Co-ordinated Collections of Microorganisms (BCCM), Laboratorium voor Microbiologie Universiteit Gent (LMG); strains kindly provided by Dr J. Leisner, Department of Veterinary Microbiology, Royal Veterinary and Agricultural University, Frederiksberg, Denmark.

into the pMOSBlue vector according to the manufacturer's recommendations (Amersham Pharmacia Biotech). The first $500 \mathrm{bp}$ were sequenced using the primers T7 ( 5'-TAATACGACTCACTATAGGG-3'), U19 (5'-GTTTTCCCAGTCACGTT-3') and 55016SR (5'-CTGCTGGCACGTAGTTAGCC-3') in a model 373 A automatic DNA sequencer (Applied Biosystems) with fluorescent dideoxy chain terminators. The $16 \mathrm{~S}$ rDNA sequences were manually aligned with the pub- lished sequence of the $16 \mathrm{~S}$ rDNA of $P$. acidilactici. Phylogenetic dendrograms were constructed by the neighbourjoining method using MicroSeq (Microbial Identification and Analysis Software, version 1.39) software (PerkinElmer Applied Biosystems).

Southern hybridization experiments. RAPD amplified fragments of all strains of $P$. acidilactici tested were separated electrophoretically in $1.5 \%$ agarose gel and transferred to 
Table 2. Sequence and description of the primers, and plasmid used in PCR experiments

\begin{tabular}{|c|c|c|c|}
\hline $\begin{array}{l}\text { Primer/ } \\
\text { plasmid }\end{array}$ & Sequence $\left(5^{\prime} \rightarrow 3^{\prime}\right)$ & Description* & Reference \\
\hline $16 \mathrm{~F}$ & AGAGTTTGATCCTGGCTCAG & & Lane (1991) \\
\hline $16 \mathrm{R}$ & CTACGGCTACCTTGTTACGA & 16S rRNA, 1500 & Lane (1991) \\
\hline rpocF & TTGATCGATGTTAATAAATTCGAA & & This study \\
\hline rpocR & GGCAAGTTGGTAATATCCGCAATC & rpoC, 2000 & This study \\
\hline ldhLF & ATGTCTAATATTCAAAATCATCAA & & This study \\
\hline ldhLR & TTATTTGTCTTGTTTTTCAGCAAG & $l d h L, 972$ & This study \\
\hline ldhDF & GGACTTGATAACGTACCCGC & & Mora et al. (1997) \\
\hline ldhDR & GTTCCGTCTTGCATTTGACC & $l d h D, 449$ & Mora et al. (1997) \\
\hline mleF & ACCATTGCGGATACGATCGAA & & This study \\
\hline mleR & CAGCTCCAAAGTCTTCAAAGT & mle, 441 & This study \\
\hline pedAF & ATACTACGGTAATGGGGT & pedA & This study \\
\hline PSRQ220† & & $\begin{array}{l}\text { Plasmid containing } \\
\text { the pediocin } \\
\text { AcH/PA-1 operon }\end{array}$ & J. Kok† \\
\hline
\end{tabular}

*Gene target and size (bp) of the amplified fragment.

†Plasmid kindly provided by Dr Jan Kok, Department of Genetics, Groningen Biomolecular Sciences and Biotechnology Institute, University of Groningen, The Netherlands.

nylon membranes (Boehringer) by Southern blotting (Sambrook et al., 1989). Plasmid pSRQ220 (Table 2) carrying the pediocin operon was used as the template for the amplification of pedAf, pedBf, pedCf and pedDf fragments as described previously (Mora et al., 1998). The amplified fragments obtained were then DIG-dUTP labelled by random priming with a labelling and detection kit (Boehringer) and used as probes in hybridization experiments. Hybridization was performed according to the manufacturer's recommendations with prehybridization and hybridization steps in $50 \%$ $\left(\mathrm{w} / \mathrm{v}\right.$ ) formamide at $42{ }^{\circ} \mathrm{C}$ and stringency washed in $0 \cdot 1 \times$ SSC at $55^{\circ} \mathrm{C}$.

Computation of strain similarities. A computer similarity analysis was done by means of the Jaccard coefficient (Sneath \& Sokal, 1973) and clustering of strains was based on the unweighted pair group method with arithmetic averages (UPGMA). The NTSYS-PC computer program (version 1.30) (Rohlf, 1987) was used in the data analysis.

Antibacterial activity test. Antibacterial activity from $P$. acidilactici strains was detected by overlaying colonies with agar containing Lactobacillus sp. strain NCK 537 and examining overlay lawns for zones of growth inhibition. $P$. acidilactici strains were grown overnight in MRS liquid medium and then the cells were serially diluted into fresh medium. One millilitre of selected dilutions containing 10-50 cells was added to $9 \mathrm{ml}$ MRS soft agar, and the mixtures were poured into Petri plates containing $10 \mathrm{ml}$ solid MRS agar. The plates were incubated at $37^{\circ} \mathrm{C}$ for $24 \mathrm{~h}$ until colonies were formed. Ten millilitres of soft MRS agar containing $100 \mu \mathrm{l}$ of an overnight culture of Lactobacillus sp. NCK 537 was subsequently overlaid on each plate. The plates were incubated overnight at $37^{\circ} \mathrm{C}$ and examined for zones of growth inhibition around $P$. acidilactici colonies. Detection of pediocin AcH/PA-1 immunity was monitored, as described above, by overlaying $P$. acidilactici PAC1.0 producer colonies with agar containing the $P$. acidilactici strains, instead of Lactobacillus sp. NCK 537. The absence of zones of growth inhibition around the PAC1.0 colonies was interpreted as evidence that the strain tested was immune to pediocin AcH/PA-1.

Determination of the amount of D- and L-lactic acid. Fifty microlitres of an overnight cell culture in MRS broth were used to inoculate $50 \mathrm{ml}$ of the same medium. After $48 \mathrm{~h}$ at $37^{\circ} \mathrm{C}$ the cells were collected by centrifugation to determine the dry weight. A $1 \mathrm{ml}$ sample of supernatant, diluted 1:50 $(\mathrm{v} / \mathrm{v})$ in distilled water, was used for the determination of $\mathrm{D}-$ and L-lactic acid, which was done using the Boehringer kit according to the manufacturer's recommendations. The amount of D- and L-lactic acid was expressed as g lactic acid per $g$ cell dry weight.

\section{RESULTS}

\section{Antibacterial activity test}

Pediocin production was evaluated for all the strains of $P$. acidilactici using Lactobacillus sp. NCK 537 as bacteriocin-sensitive test strain as described in Methods. Only strains PAC1.0, F, Psp2, JD1-23 and UL5 showed colonies with zones of growth inhibition. When $P$. acidilactici strains were used as test strains against colonies of strain PAC1.0, zones of growth inhibition were observed for 12 strains (strains DSMZ 20284 ${ }^{\mathrm{T}}$, DSMZ 20238, ATCC 8042, ATCC 12697, ATCC 25740, PG, Pdi11, LMG 17674, LMG 17680, LMG 17687, LMG 17689 and LMG 17692) while the remaining six strains (PAC1.0, F, Psp2, JD1-23, UL5 and the PAC1.0 cured strain PAC750F) were immune to pediocin AcH/PA-1. The results for strain PAC750F confirmed that this strain had acquired resistance to the pediocin despite the loss of the plasmid-encoded genetic determinant of immunity, as suggested by Venema et al. (1995). Bacteriocin phenotypes of the tested strains are summarized in Table 1. 

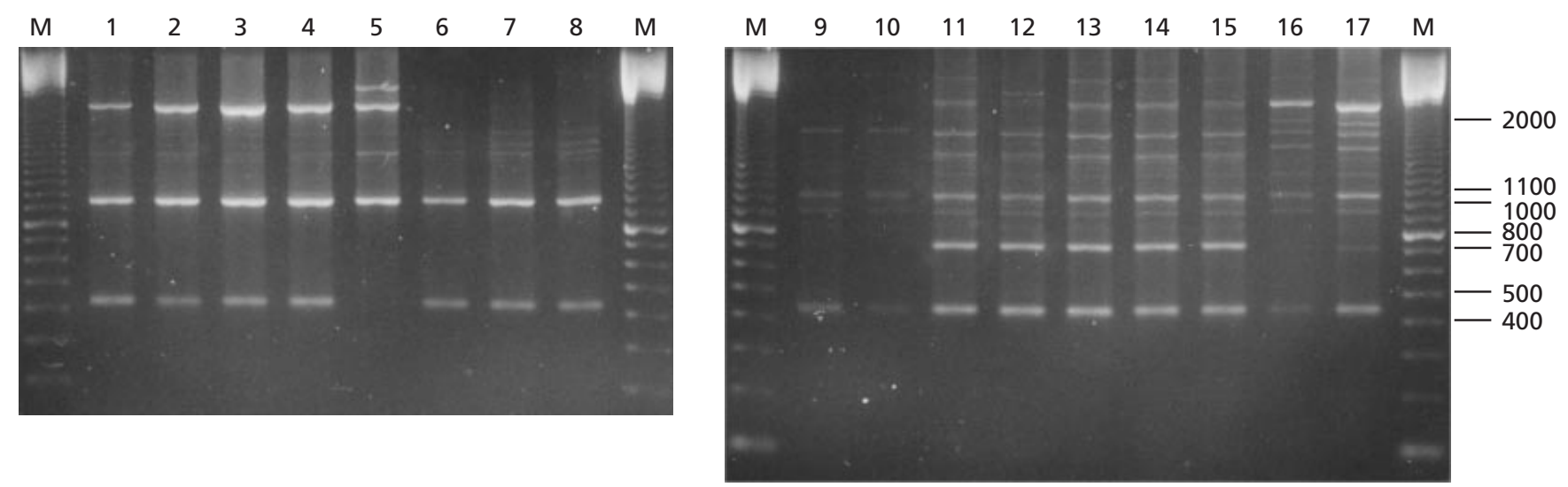

Fig. 1. RAPD patterns of $P$. acidilactici strains, using the primer pedAf. Lanes $1-5$, strains DSMZ 20284 ${ }^{\top}, D_{S M Z} 20238$, ATCC 8042, ATCC 12697 and ATCC 25740; lanes 6-8, strains LMG 17674, LMG 17687 and LMG 17689; lanes 9 and 10 , strains Pdi11 and PG; lanes 11-15, strains PAC1.0, Psp2, F, UL5 and JD-23; lanes 16 and 17, strains LMG 17680 and LMG 17692; M, molecular mass marker 100 bp ladder (Amersham-Pharmacia Biotech).

\section{Metabolic profiles}

The $P$. acidilactici strains were analysed for their ability to ferment several carbohydrates. All the tested strains were able to acidify BSM medium in the presence of trehalose, D-xylose, D-glucose, D-fructose, D-mannose and galactose as sole carbon source, after $24 \mathrm{~h}$ incubation at $37^{\circ} \mathrm{C}$. Weak acidification was detected for all the strains in the presence of rhamnose after more than $48 \mathrm{~h}$ incubation. Strains Pdi11 and PG acidified the medium in the presence of L-arabinose; strains PAC1.0, Psp2, F, JD1-23, UL5, PAC750F, LMG 17680 and LMG 17692 fermented sucrose. Strains LMG 17680 and LMG 17692 fermented melibiose and raffinose. None of the strains fermented inositol, sorbose, maltose, lactose or D-melezitose.

\section{RAPD analysis and amplification of the pediocin AcH/PA-1 operon genes}

In order to type $P$. acidilactici strains and to differentiate the pediocin producer strains, RAPD analysis was carried out using, in low-stringency conditions, a primer targeted to the plasmid gene (pedA) encoding pediocin AcH/PA-1 (Marugg et al., 1992; Motlagh et al., 1994). The reproducibility of RAPD analysis was tested by comparing the amplified patterns of different DNA extractions and of several amplification reactions. As shown in Fig. 1, the tested strains showed six amplification pattern profiles. One profile, typical of strains DSMZ 20284 ${ }^{\mathrm{T}}$, DSMZ 20238, ATCC 12697 and ATCC 8042 , showed three main amplified fragments of about 450, 950 and $2200 \mathrm{bp}$. The $450 \mathrm{bp}$ fragment was also present in the remaining strains, with the exception of ATCC 25740. An analogous pattern was observed from strains LMG 17674, LMG 17687 and LMG 17689, which showed the 450 and $950 \mathrm{bp}$ fragments. A marked $700 \mathrm{bp}$ amplified fragment and a $1350 \mathrm{bp}$ band permitted grouping of all the pediocin producer strains (PAC1.0, Psp2, F, JD1-23, UL5) and the PAC1.0 cured strain
PAC750F. Identical RAPD profiles were observed among the pediocin producers and the PAC1.0 cured strain, suggesting that the plasmid harbouring the pediocin determinant was not involved in the amplification. Moreover Southern hybridization performed on the RAPD patterns profiles using pedAf, pedBf, pedCf and pedDf fragments as probes, showed that none of the RAPD fragments originated from the pediocin $\mathrm{AcH} / \mathrm{PA}-1$ operon despite the fact that a primer targeted at the pedA gene was used (data not shown).

Identical RAPD pattern profiles were observed among strains PAC1.0, F and Psp2, which were known to carry the plasmid harbouring the pediocin $\mathrm{AcH} / \mathrm{PA}-1$ operon, and strains JD1-23 and UL5, suggesting that these strains are highly related. PCR experiments performed with primers targeted to the four genes involved in pediocin AcH/PA-1 production, as previously described (Mora et al., 1998), confirmed that strains JD1-23 and UL5 also had the genetic determinants related to pediocin $\mathrm{AcH} / \mathrm{PA}-1$ production. Analogous PCR experiments performed on all the other non-producing strains gave negative results.

\section{Primary metabolism housekeeping genes: restriction analysis of the $I d h D$ and $I d h L$ genes}

To investigate if the variability highlighted by RAPD analysis was the consequence of a wide and consolidated genetic diversity among the tested strains rather than the effect of the presence of minimal sequence variation fortuitously detected by the pedAF primer, several housekeeping genes were analysed. Restriction analysis of the 449 bp $l d h D f$ amplified fragment, previously used for the specific PCR identification of the $P$. acidilactici strains (Mora et al., 1997), was carried out using five four-cutting restriction enzymes (AluI, HaeIII, HhaI, HpaII, RsaI). While restriction analysis using HaeIII and $H p a I I$ did not reveal any sequence variation in the $l d h D f$ 
(a) IdhDf

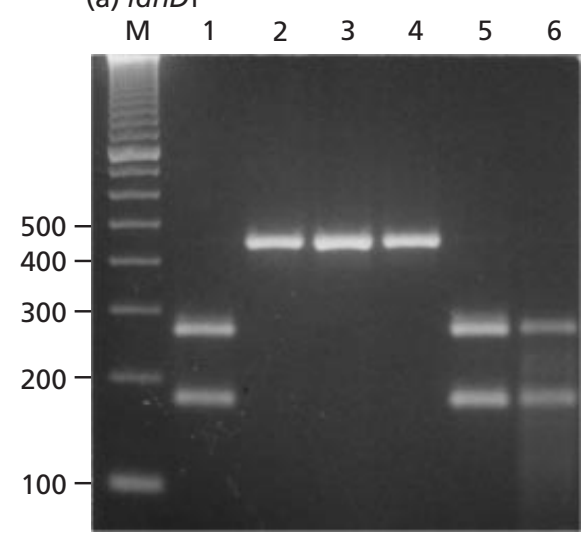

Hhal

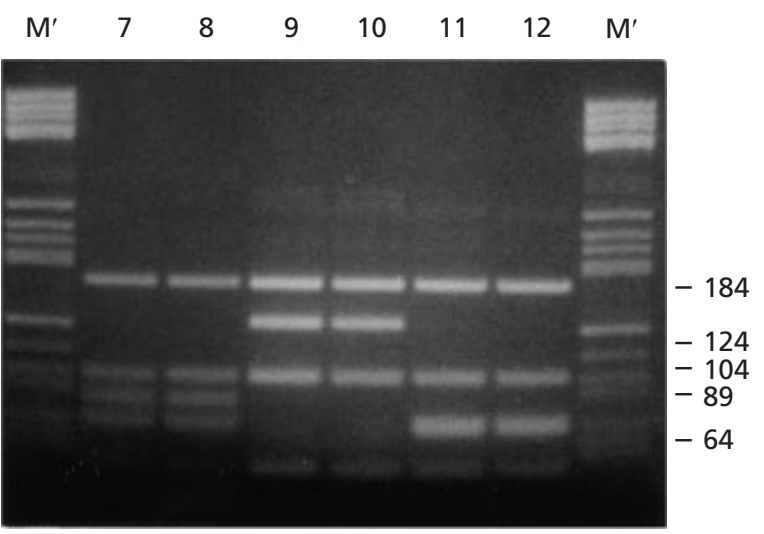

Alul + Rsal

(b) IdhLf

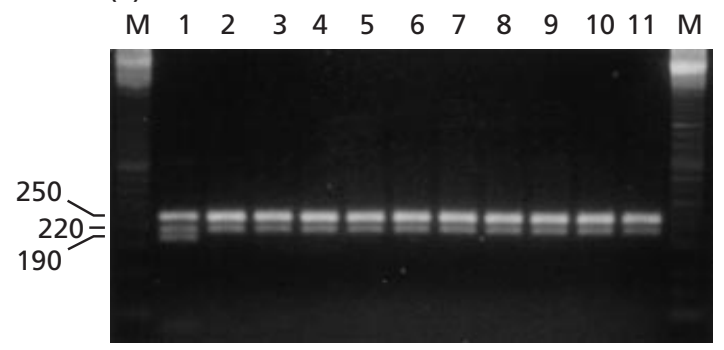

Hhal
M $1213141516171819202122 \quad M$

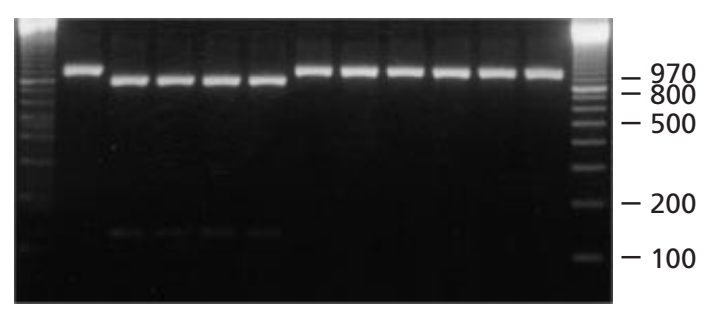

Haelll

(c) mlef

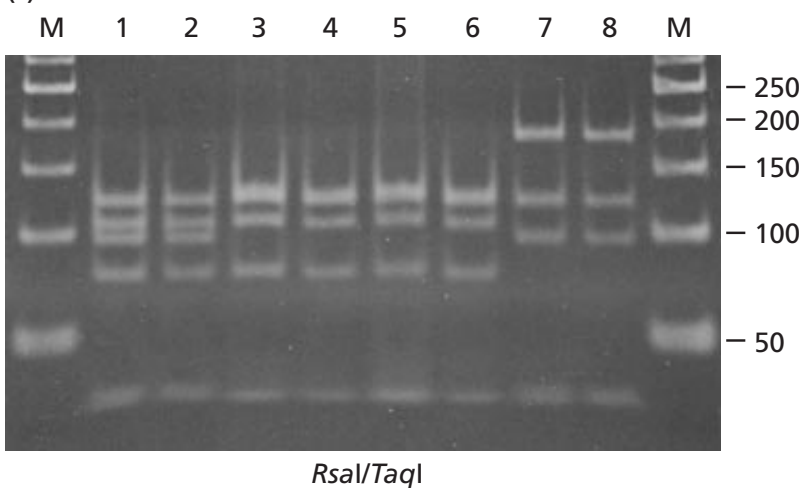

(d) $\mathrm{rpoCf}$

$\begin{array}{llllllllllll}\text { M } & 1 & 2 & 3 & 4 & 5 & 6 & 7 & 8 & 9 & 10 & M\end{array}$

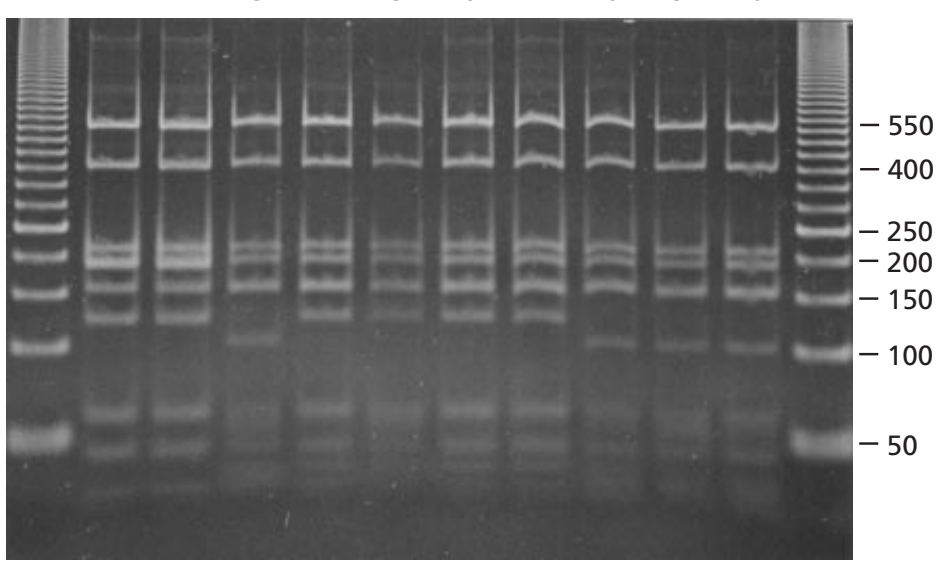

Alul + Rsal

Fig. 2. (a) Agarose gel electrophoresis showing the restriction profiles of amplified IdhDf fragment of $P$. acidilactici strains obtained using Hhal (lanes 1-6) and the double digestion Alul+Rsal (lanes 7-12). Lane 1, strain DSMZ 20284 ; 
Table 3. PCR and restriction patterns of the tested strains

\begin{tabular}{|c|c|c|c|c|c|c|}
\hline \multirow{2}{*}{$\begin{array}{l}\text { P. acidilactici } \\
\text { strain }\end{array}$} & \multicolumn{5}{|c|}{ PCR and RFLP pattern* } & \multirow{2}{*}{$\begin{array}{l}\text { Bacterial } \\
\text { genotype }\end{array}$} \\
\hline & $\begin{array}{l}\quad r p o C f \\
\text { restriction }\end{array}$ & $\begin{array}{l}L d h L f \\
\text { restriction }\end{array}$ & $\begin{array}{l}l d h D f \\
\text { restriction }\end{array}$ & $\begin{array}{c}\text { mlef } \\
\text { restriction }\end{array}$ & RAPD & \\
\hline DSMZ $20284^{\mathrm{T}}$ & $\mathrm{C}$ & $\mathrm{D}$ & $\mathrm{E}$ & $\mathrm{F}$ & G & \multirow[t]{2}{*}{ I } \\
\hline DSMZ 20238 & $\mathrm{C}$ & D1 & E1 & $\mathrm{F}$ & G & \\
\hline ATCC 8042 & $\mathrm{C}$ & D1 & E1 & $\mathrm{F}$ & G & \multirow[t]{2}{*}{ II } \\
\hline ATCC 12697 & $\mathrm{C}$ & D1 & E1 & $\mathrm{F}$ & G & \\
\hline ATCC 25740 & $\mathrm{C}$ & D1 & $\mathrm{E}$ & $\mathrm{F}$ & G1 & \multirow[t]{2}{*}{ III } \\
\hline LMG 17674 & $\mathrm{C}$ & D2 & $\mathrm{E}$ & $\mathrm{F} 1$ & $\mathrm{G} 2$ & \\
\hline LMG 17687 & $\mathrm{C}$ & D2 & $\mathrm{E}$ & $\mathrm{F} 1$ & G2 & \multirow[t]{2}{*}{ IV } \\
\hline LMG 17689 & $\mathrm{C}$ & D2 & $\mathrm{E}$ & $\mathrm{F} 1$ & G2 & \\
\hline Pdi11 & $\mathrm{C} 1$ & D2 & $\mathrm{E} 2$ & $\mathrm{~F} 2$ & G3 & \multirow{2}{*}{ V } \\
\hline PG & $\mathrm{C} 1$ & D2 & $\mathrm{E} 2$ & $\mathrm{~F} 2$ & G3 & \\
\hline LMG 17680 & $\mathrm{C} 2$ & D2 & E3 & $\mathrm{F} 1$ & G4 & \multirow{4}{*}{ VI } \\
\hline LMG 17692 & $\mathrm{C} 2$ & D2 & E3 & $\mathrm{F} 1$ & G4 & \\
\hline PAC1.0 & $\mathrm{C} 1$ & D2 & E3 & $\mathrm{F} 2$ & G5 & \\
\hline PAC750F & $\mathrm{C} 1$ & D2 & E3 & $\mathrm{F} 2$ & G5 & \\
\hline Ped F & $\mathrm{C} 1$ & D2 & E3 & $\mathrm{F} 2$ & G5 & \multirow{4}{*}{ VII } \\
\hline JD1-23 & $\mathrm{C} 1$ & D2 & E3 & $\mathrm{F} 2$ & G5 & \\
\hline UL5 & $\mathrm{C} 1$ & D2 & E3 & $\mathrm{F} 2$ & G5 & \\
\hline Psp2 & $\mathrm{C} 1$ & D2 & E3 & $\mathrm{F} 2$ & G5 & \\
\hline
\end{tabular}

*Letter/number codes indicate different DNA haplotypes.

† Bacterial genotypes obtained by UPGMA computer analysis.

fragments, an unexpected polymorphism was detected using the remaining three enzymes. Based on the results obtained (Fig. 2a, Table 3) the strains were clustered in four distinct sequence groups. The first group was constituted by strains DSMZ 20238, ATCC 8042 and ATCC 12697; the second sequence cluster included all the pediocin producer strains (PAC1.0, Psp2, F, JD1-23 and UL5), two chili bo isolates (LMG 17680, LMG 17692) and the PAC1.0 cured strain; the third group included strains DSMZ 20284 ${ }^{\mathrm{T}}$, ATCC 25740, LMG 17674, LMG 17687 and LMG 17689. The fourth group was constituted by strains Pdi11 and PG. It is interesting to note that the sizes of the restriction fragments of the amplified $l d h D f$ were in agreement with the theoretical analysis of the published sequence (Garmyn et al., 1995a) only for the pediocin producer strains.
A lower degree of variability was observed when the $l d h L$ gene was analysed. The entire $972 \mathrm{bp}$ coding sequence of the $l d h L$ gene (ldhLf) was amplified using the primers (Table 2) selected from published sequence (Garmyn et al., 1995b). Restriction analysis was performed using the above-mentioned five restriction enzymes. Restriction analysis using HhaI and HaeIII highlighted three different $l d h L$ alleles among the 17 strains analysed, while no differences were detected using AluI, HpaII and RsaI. One sequence was characteristic of strain DSMZ $20284^{\mathrm{T}}$, one typical of strains DSMZ 20238, ATCC 8042, ATCC 12697 and ATCC 25740, and one typical of strains Pdi11, PG, PAC1.0, Psp2, F, JD1-23, UL5, LMG 17674, LMG 17680, LMG 17687, LMG 17689, LMG 17692 and the PAC1.0 cured strain PAC750F. The sizes of the restriction fragments

lanes 2-4: strains DSMZ 20238, ATCC 8042 and ATCC 12697; lane 5, strain Pdi11; lane 6, strain PG; lanes 7 and 8, strains DSMZ 20284 ${ }^{\top}$ and DSMZ 20238; lanes 9 and 10, strains Pdi11 and PG; lanes 11 and 12, strains PAC1.0 and Psp2; M, molecular mass marker $100 \mathrm{bp}$ ladder (Amersham-Pharmacia Biotech); $\mathrm{M}^{\prime}$ ', molecular mass marker $\mathrm{V}$ (Boehringer), 587, 540, 504, 458, 434, 267, 234, 231, 192, 184, 124/123, 104, 89, 80/64/57/51/21/18/11/8 bp. (b) Agarose gel electrophoresis showing the restriction profiles of IdhLf amplified fragment of $P$. acidilactici strains obtained using Hhal (lanes 1-11) and Haelll (lanes 12-22). Lane 1, strain DSMZ 20284 ${ }^{\top}$; lanes 2-11, strains DSMZ 20238, ATCC 8042, ATCC 12697, ATCC 25740, Pdi11, PG, PAC1.0, F, Psp2 and JD1-23; lane 12, strain DSMZ 20284 ${ }^{\top}$; lanes 13-16, strains DSMZ 20238, ATCC 8042, ATCC 12697 and ATCC 25740; lanes 17-22, strains Pdi11, PG, PAC1.0, F, Psp2 and JD1-23; M, molecular mass marker 100 bp ladder (Amersham-Pharmacia Biotech); (c) PAGE showing the restriction profiles of amplified mlef fragment of $P$. acidilactici strains obtained using the double digestion Rsal+Taql. Lanes 1 and 2, strains LMG 17680 and LMG 17674 ; lanes 3-6, strains F, PAC1.0, Pdi11 and PG; lanes 7 and 8, strains ATCC 25740 and DSMZ 20238; M, molecular mass marker $50 \mathrm{bp}$ ladder (Amersham-Pharmacia Biotech); (d) PAGE showing the restriction profiles of amplified $r$ poCf fragment of $P$. acidilactici strains obtained using the double digestion Alul + Rsal. Lanes 1 and 2, strains LMG 17692 and LMG17680; lane 3, strain LMG 17689; lanes 4-7, strains UL5, F, PG, pdi11; lanes 8-10, strains ATCC 25740, ATCC 12697 and DSMZ 20238; $\mathrm{M}$, molecular mass marker 50 bp ladder (Amersham-Pharmacia Biotech). 


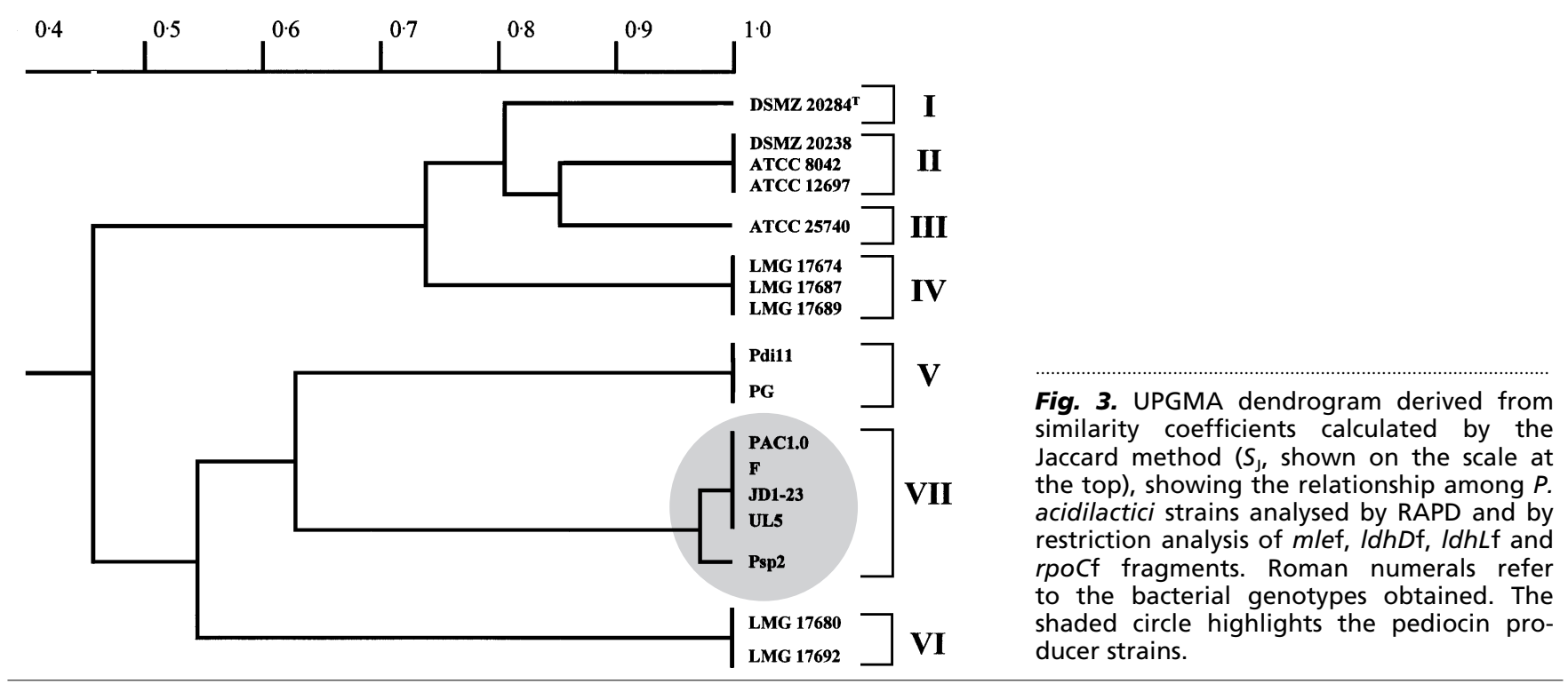

obtained were in agreement with the theoretical analysis of the sequence only for the $l d h L f$ fragments amplified from the group of strains comprising the pediocin producers (Fig. 2b, Table 3).

\section{Primary metabolism non-housekeeping genes: restriction analysis of the mle gene}

Restriction analysis of the first $441 \mathrm{bp}$ of the gene encoding malolactic enzyme (mlef) was carried out using AluI, HhaI and RsaI. AluI digestion did not permit discrimination among the strains tested, while RsaI and TaqI highlighted three different mle alleles: one characteristic of strains DSMZ 20284 ${ }^{\mathrm{T}}$, DSMZ 20238, ATCC 8042, ATCC 12697 and ATCC 25740, one charcteristic of pediocin-producing strains and of PG and Pdi11 strains, and another typical of all chili bo isolates. The sizes of the restriction fragments obtained were in agreement with the theoretical analysis of the sequence published (Groisillier \& Lonvaud-Funel, 1999) only for the mlef fragments amplified from the group of strains obtained from DSMZ and ATCC (Fig. 2c, Table 3).

\section{Housekeeping gene involved in transcription and translation machinery: rpoC}

Further genetic investigation was then carried out on the $r p o C$ gene to investigate if the high degree of variability highlighted by the previous analysis was also present in this more conserved chromosomal region. When the first $2000 \mathrm{bp}$ of the coding region of the rpoC gene (rpoCf) was analysed, the degree of sequence variation observed was similar to that detected by analysing the $l d h$ genes: three $r p o C$ alleles were observed using $A l u \mathrm{I}$, RsaI, HpaII and HindIII. One sequence was characteristic of strains DSMZ 20284 ${ }^{\mathrm{T}}$, DSMZ 20238, ATCC 8042, ATCC 12697, ATCC 25740, LMG 17674, LMG 17687 and LMG 17689, one typical of strains Pdi11, PG, PAC1.0, Psp2, F, JD1-23, UL5 and the PAC1.0 cured strain, and another typical of strains LMG 17680 and
LMG 17692 (Fig. 2d, Table 3). The sizes of the restriction fragments obtained were in agreement with the theoretical analysis of the published sequence (Morse et al., 1996) only for the rpoCf fragments amplified from strains DSMZ 20284 ${ }^{\mathrm{T}}$, DSMZ 20238, ATCC 8042, ATCC 12697 and ATCC 25740 and for strains LMG 17674, LMG 17687 and LMG 17689.

\section{Numerical analysis of PCR and restriction profiles}

A computer similarity and clustering analysis of $P$. acidilactici strains was performed on the data from all the PCR and restriction experiments. A UPGMA dendrogram derived from similarity coefficients calculated by the Jaccard method revealed that two main clusters separated at a similarity level of 0.46 (Fig. 3). All the pediocin producer strains were grouped together at a high similarity level $(0.97)$ and belonged to the same main cluster comprising the subgrouping of strains Pdi11, PG and the chili bo isolates LMG 17680 and LMG 17692. The remaining chili bo isolates (LMG 17674, LMG 17687 and LMG 17689) were grouped in the other main branch separated at a similarity level of 0.75 from all the strains obtained from DSMZ and ATCC. As shown in Fig. 3, it was possible to detect seven genotypic groups with a similarity higher than $80 \%$.

\section{S rDNA partial sequencing and phylogenetic analysis}

Two strains for genotype VII (PAC1.0 and Psp2) and one strain for each of genotypes I to VI (DSMZ 20284 ${ }^{\mathrm{T}}$, DSMZ 20238, ATCC 25740, LMG 17674, Pdi11 and LMG 17680) were selected for $16 \mathrm{~S}$ rDNA sequencing. Sequences were obtained for the region 8-524 (E. coli numbering) of the $16 \mathrm{~S} \mathrm{rDNA}$, encompassing the variable regions $\mathrm{V} 1, \mathrm{~V} 2$ and $\mathrm{V} 3$. The sequences of each of the eight strains were used to search the GenBank and EMBL databases with the aim of finding the closest LAB 
Table 4. 16S rDNA signature sequences of $P$. acidilactici strains

GenBank accession numbers for the sequences used in this table and in the construction of the phylogenetic tree (Fig. 4) are: $P$. acidilactici DSMZ 20284 ${ }^{\mathrm{T}}$, M58833 (Collins et al., 1990); DSMZ 20284 ${ }^{\mathrm{T}}$, AJ249535 (this work); DSMZ 20238, AJ249539; ATCC 25740; AJ249537; LMG 17680, AJ249891; LMG 17687, AJ249538; PAC1.0, AJ249893; Psp2, AJ249894; Pdi11, AJ249892; LA3, AB018213; LA35, AB018214; P. pentosaceus DSMZ 20336, M58834; LS5, AB018215). Bold type indicates differences from the sequence for DSMZ $20284^{\mathrm{T}}$ determined in this work (top line).

\begin{tabular}{|c|c|c|c|c|c|c|c|c|c|c|c|c|}
\hline \multirow[t]{2}{*}{ Strain } & \multirow[t]{2}{*}{ Genotype } & \multicolumn{11}{|c|}{ Position $\dagger$} \\
\hline & & $33-36$ & $73-79$ & $92-96$ & $126-129$ & $253-257$ & $271-273$ & $307-314$ & $324-327$ & $411-414$ & $422-427$ & $502-505$ \\
\hline P. acidilactici DSMZ $20284^{\mathrm{T}}$ & I & ACGC & GATCAGGA & AACACG & GGTAA & GGTGA & $\mathrm{CAA}$ & CGGCCACA & AGGC & AGAA & GGCTCG & $\mathrm{GA}-\mathrm{AA}$ \\
\hline P. acidilactici DSMZ $20284^{\mathrm{T}} \neq$ & & ACGC & GATCAGGA & $A A \mathbf{Y} A \mathbf{Y} G$ & GGTAA & GGTGA & $\mathrm{CAA}$ & CGGCCACA & $\mathbf{N} G \mathbf{A C}$ & AGAA & GGCTCG & $\mathrm{GA}-\mathrm{GA}$ \\
\hline P. acidilactici DSMZ 20238 & II & ACGC & GATCAGGA & AACACG & GGTAA & GGTGA & CAA & CGGCCACA & $\mathrm{AG} \mathbf{A C}$ & AGAA & GGCTCG & GA-GA \\
\hline P. acidilactici ATCC 25740 & III & ACGC & GATCAGGA & AACACG & GGTAA & GGTGA & CAA & CGGCCACA & $\mathrm{AGAC}$ & $\mathrm{AAAA}$ & GGCTCG & $\mathrm{GA}-\mathrm{GA}$ \\
\hline P. acidilactici LMG 17680 & VI & ACGC & GATTATGA & AACACG & GGTAA & GGTGA & $\mathrm{CAA}$ & CGGCCACA & $\mathrm{AG} \mathbf{A C}$ & AGAA & GGCTCG & $\mathrm{GA}-\mathrm{GA}$ \\
\hline P. acidilactici LMG 17687 & IV & ACGC & GATCAGGA & AATATG & GGTAA & GGTGA & $\mathrm{CTA}$ & CGGCCACA & $\mathrm{A} G \mathbf{A C}$ & AGAA & GGTTCG & $\mathrm{GA}-\mathrm{GA}$ \\
\hline P. acidilactici Pdi11 & $\mathrm{V}$ & $\mathrm{ACAC}$ & GATTATGA & AACACG & GGTAA & GGTGA & $\mathrm{CAA}$ & CGGCCACA & $\mathrm{AGAC}$ & AGAA & GGCTCG & $\mathrm{GA}-\mathrm{GA}$ \\
\hline P. acidilactici $\mathrm{PAC} 1.0$ & VII & ACGC & GATTATGA & AACACG & GGCAA & GGTGA & CAA & CGGCCACA & $\mathrm{AGAC}$ & AGAA & GGCTCG & $\mathrm{GA}-\mathrm{GA}$ \\
\hline P. acidilactici Psp2 & VII & ACGC & GATTATGA & AACACG & GGCAA & GGTGA & $\mathrm{CAA}$ & CGGCCACA & $\mathrm{AGAC}$ & AGAA & GGCTCG & GA-GA \\
\hline P. acidilactici LA3S & & ACGC & GATTATGA & AACACG & GGTAA & $\mathrm{GGC} G A$ & CAA & CGGCCASA & $\mathrm{AGAC}$ & AGAA & GGCTCG & $\mathrm{GA}-\mathrm{GA}$ \\
\hline$P$. acidilactici $\mathrm{LA} 35 \mathbb{S}$ & & ACGC & GATTATGA & AACACG & GGTAA & GGTGA & CAA & $\mathrm{CG}-\mathrm{CCACA}$ & $\mathrm{AGAC}$ & AGAA & GGCTTG & GAAGA \\
\hline P. pentosaceus DSMZ 20336ł & & ACGC & GATTATGA & AACACG & GGTAA & GGTGA & CAA & CGGCCACA & $\mathrm{A} G \mathbf{A C}$ & AGAA & GGCTCG & $\mathrm{A} A-\mathrm{GA}$ \\
\hline
\end{tabular}

* Roman numerals refer to the bacterial genotypes obtained by UPGMA analysis (Fig. 3).

$\dagger$ E. coli numbering.

‡ Sequence reported by Collins et al. (1990).

SSequence reported by Cai et al. (1999).

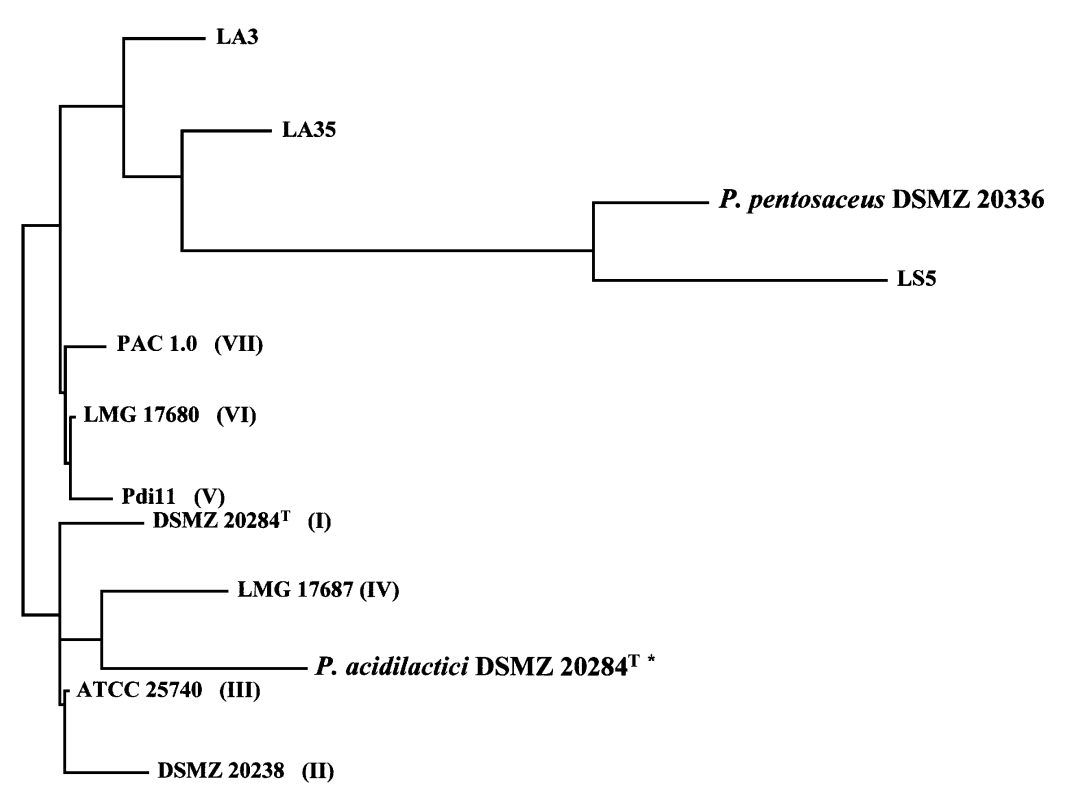

$182 \%$

Fig. 4. Phylogenetic relationship of $P$. acidilactici strains based on the neighbourjoining method. Roman numerals, in parentheses, refer to the bacterial genotypes obtained by UPGMA analysis (Fig. 3). *Sequence published by Collins et al. (1990).

species. The sequences of strains PAC1.0 and Psp2 were identical. The region 8-524 (E. coli numbering) was aligned and compared with that published for $P$. acidilactici DSMZ 20284 ${ }^{\mathrm{T}}$, LA3 and LA35 and with that of the closest relatives $P$. pentosaceus DSMZ 20336 and LS5. For all the eight tested sequences high similarity values $(97 \cdot 2-99 \cdot 5 \%$ ) were found with the $16 \mathrm{~S} \mathrm{rDNA}$ of $P$. acidilactici DSMZ 20284 ${ }^{\mathrm{T}}$, LA3 and LA35, while lower values ranging from $94.7 \%$ to $96.2 \%$ were found with P. pentosaceus DSMZ 20336 and LS5. Signature sequences typical of each representative strain analysed are shown in Table 4. The phylogenetic tree based on neighbour-joining is shown in Fig. 4.

\section{Variation among strains in production of $D$ - and L-lactic acid}

To investigate if the remarkable intraspecific variability highlighted by analysing the $l d h$ genes was also reflected in the phenotype of the strains studied, the amount of $\mathrm{D}^{-}$ 
and L-lactic acid produced was evaluated for one or two strains of each $l d h D / L$ sequence type previously detected. The amount of D-lactic acid produced ranged from 0.8 to $2.4 \mathrm{~g}$ of lactic acid (g dry weight $)^{-1}$, while $\mathrm{L}^{-}$ lactic acid ranged between 2 and $3.7 \mathrm{~g}$ (g dry weight $)^{-1}$. For all the analysed strains the production of L-lactic acid was higher (by $60-72 \%$ ) than that of D-lactic acid. Despite the degree of variability detected among the strains the variability did not reflect the genetic polymorphism previously observed.

\section{DISCUSSION}

In this study we used several DNA fingerprinting techniques to characterize 17 strains of $P$. acidilactici isolated from different environments such as vegetables, sour dough, fermented sausages and cheese. PCR experiments on strains JD1-23 and UL5, known to produce the pediocins JD and 5 respectively, revealed that they had the genetic determinants related to pediocin $\mathrm{AcH} / \mathrm{PA}-1$ production. These results strongly suggest that the three pediocins (AcH/PA-1, JD1-23, 5) are probably identical. The practice of premature naming, before knowing the amino acid sequence of bacteriocins, has often resulted in assigning two or more names to the same bacteriocin (Ray, 1996).

With the aim of seeking a genomic/phylogenetic relationship among $P$. acidilactici strains and to verify if the molecular characteristics were correlated with their ecological origin, all the strains were analysed using a RAPD protocol, by the restriction analysis of several housekeeping genes, and by partial sequencing of the $16 \mathrm{~S}$ rRNA gene.

A modified RAPD protocol using a single primer targeted to the gene encoding the pediocin AcH/PA-1 was able to group together all the pediocin producer strains, and detect another six distinct pattern types. Despite the use of a primer targeted at the pedA gene and the generation of an identical amplification profile among the pediocin producer strains, none of the RAPD fragments was generated from the pediocin operon, as demonstrated by hybridization experiments and by the fact that PAC1.0 and the cured strain PAC750F derived from it showed the same amplification pattern. The genetic variability detected by RAPD analysis was also reflected in several housekeeping genes, showing that a wide and consolidated genetic diversity among the tested strains was present.

A high degree of variability and an analogous clustering of the strains were observed by the restriction analysis of an amplified fragment originating from the $l d h D$ gene, while the same analysis on the $l d b L$ gene revealed a lower degree of intraspecific variability. These results agree with the fact that the nucleotide sequence of the $l d h L$ gene is more conserved among different species of lactic acid bacteria than that of the $l d h D$ gene (Garmyn et al., 1995a, b). All the pediocin producer strains were grouped together by analysis of the $l d h D$ gene, while they were grouped with strains Pdi11 and PG by analysis of the $l d h L$ gene. Analysis of part of the mle coding sequence confirmed the close relation among pediocin producer strains and strains Pdi11 and PG. Furthermore all the chili bo strains were clearly clustered together and separated from the other strains of different isolation source.

The high degree of variability discovered in the $l d h$ genes was phenotypically tested by the evaluation of the amount of $\mathrm{D}$ - and L-lactic acid produced by $P$. acidilactici strains. All the tested strains exhibited a non-racemic production of the two lactic acid enantiomeric forms, with proportionately more L-lactic acid. Despite a certain degree of variability present among the strains, it was not possible to find any direct correlation between the phenotypic and the genotypic data. Intraspecific variability in the $l d h$ gene sequences was also observed in Lactococcus lactis strains and it was found consistent with the $16 \mathrm{~S}$ rRNA genotype but not with the phenotype (Urbach et al., 1997).

The results obtained by analysing the $r p o C$ gene were similar to those obtained with the $l d h$ genes; three different $r p o C$ alleles were detected. The DNA-dependent RNA polymerase has a fundamental role in cell biology that justifies the hypothesis of its ancient origin in evolutionary terms and is in accordance with the fact that it appears to be maintained throughout most species of bacteria (Morse et al., 1996). Nevertheless it was possible to detect a certain degree of variability among the analysed strains. This result was unexpected but could be an indication of a marked intraspecific variability in the species $P$. acidilactici.

The dendrogram summarizing the data obtained showed two main branches in the species, the first including strains obtained from DSMZ and ATCC (most of which were isolated from vegetables) and three chili bo isolates (LMG 17674, LMG 17687 and LMG 17689), and the second branch including sour-dough isolates, pediocin producer strains and the remaining chili bo isolates. In this second main branch, sour-dough strains, pediocin producer strains and chili bo isolates were well separated and represent three distinct clusters that seem directly related to the metabolic traits of the strains and partially related to their ecological origin. Specifically, sucrose-positive and pediocin-producing strains (most of them isolated from meat products) represent genotype VII, arabinose-positive strains isolated from sourdough samples represent the nearest genotype V, while sucrose-, melibiose- and raffinosepositive strains (LMG 17680 and LMG 17692) represent genotype VI. The remaining chili bo strains (LMG 17674, LMG 17687 and LMG 17689) were clustered in genotype IV. It was not possible to detect phenotypic evidence for genotypes I, II, III and IV, except that all these strains were arabinose-, sucrose-, melibiose- and raffinose-negative. Relationships among genotypic analysis and acidification in presence of carbohydrates were also recently observed in Pediococcus acidilactici and P. pentosaceus strains (Cai et al., 1999) and in Lactobacillus garvieae strains (Eldar et al., 1999). 
With the exception of strain ATCC 12697, whose isolation source is not known, the four genotypes I, II, III, IV seem to be related to the ecological origin of the strains: strain DSMZ $20284^{\mathrm{T}}$ was isolated from barley, strains DSMZ 20238 and ATCC 8042 from 'mash', strain ATCC 25740 from 'plants', while strains LMG 17674, LMG 17687 and LMG 17689 were all isolated from chili bo.

The variability revealed by analysis of the proteincoding housekeeping and non-housekeeping genes (rpoC, $l d h D / L$ and mle) was confirmed by the partial $16 \mathrm{~S}$ rDNA sequencing of representative strains of each genotype obtained. The phylogenetic analysis substantiates the hypothesis that each genotype obtained could represent a genomic and/or evolutionary subpopulation within the species $P$. acidilactici. The $16 \mathrm{~S}$ rDNA sequencing was also consistent with the fact that genotypes I, II, III and IV were different genotypes. Our findings seem to agree with the suggestion by Palys et al. (1997) that while 16S rRNA sequence data are useful for distinguishing moderately divergent populations into separate sequence clusters, protein-coding genes provide a better opportunity for distinguishing very closely related ecological populations. These authors also suggested that the inability of $16 \mathrm{~S}$ rRNA sequences to distinguish some taxa is a consequence of the low evolutionary rate of the $16 \mathrm{~S}$ rRNA genes. In this context we could suppose that each genetic subpopulation detected in $P$. acidilactici could be relatively ancient in evolutionary terms, because few but significant substitutions were detected among the $16 \mathrm{~S}$ rDNA sequences of the analysed strains. Some discrepancies were observed in strain DSMZ 20284 ${ }^{\mathrm{T}}$ between the published $16 \mathrm{~S}$ rDNA sequence and that determined in this study. Some of these differences were due to the presence of ambiguities in the published sequence, while the others could be the consequence of an intra-chromosomal sequence polymorphism in the analysed strain.

A wide selection of different environments of isolation of $P$. acidilactici were considered and seven different genotypes or genomic subpopulations were detected. Three of these genomic subpopulations were found to be consistent with the phenotype. We could speculate that the strains able to utilize some carbohydrates and/or to produce pediocin have a strong competitive advantage that should have allowed the evolution of the genome in a different way compared with strains which do not have these metabolic features or that colonize other ecological niches. In this context, chili bo isolates, despite having the same isolation source, were clustered in two different genetic subpopulations. Pediocin $\mathrm{AcH} / \mathrm{PA}$-1-producing strains were isolated from meat products and from cheddar cheese, and despite the fact that no $\mathrm{Ped}^{-}$strains from the same products were included in this study (we were unable to obtain, or find in the literature, any examples of such strains), our data strongly suggested that they represent a homogeneous subpopulation in the species.

In conclusion, the multilocus typing approach, as carried out in this study, should be considered as a useful tool for the determination of the population structure in the species $P$. acidilactici, and the data obtained from this kind of approach should be more accurate and precise than those obtained by the analysis of a single locus.

\section{ACKNOWLEDGEMENTS}

This research was supported by a grant of the Ministry of the University and Technological and Scientific Research (ex MURST $40 \%$ ).

We thank Dr Giorgio Giraffa and Dr Lucia Senini (Istituto Sperimentale Lattiero Caseario, Lodi, Italy) for their invaluable collaboration during the phylogenetic analysis. We also acknowledge Dr E. Emond, Professor B. Huutkins, Professor T. R. Klaenhammer, Professor Galli Volonterio, Dr G. Giraffa, Dr J. Leisner and Professor B. Ray for providing strains of $P$. acidilactici.

\section{REFERENCES}

Back, W. \& Stackebrandt, E. (1978). DNS/DNS-Homologiestudien innerhalb der Gattung Pediococcus. Arch Microbiol 118, 79-85.

Bhunia, A. K., Johnson, M. C. \& Ray, B. (1988). Purification, characterization and antimicrobial spectrum of a bacteriocin produced by Pediococcus acidilactici. J Appl Bacteriol 65, 261-268.

Bhunia, A. K., Johnson, M. C., Ray, B. \& Kalchayan, N. (1991). Mode of action of pediocin AcH from Pediococcus acidilactici $\mathrm{H}$ on sensitive bacterial strains. J Appl Bacteriol 70, 25-33.

Cai, Y., Kumai, S., Ogawa, M., Benno, Y. \& Nakase, T. (1999). Characterization and identification of Pediococcus species from forage crops and their application for silage preparation. Appl Environ Microbiol 65, 2901-2906.

Chen, Y., Ludescher, R. D. \& Montville, T. J. (1997). Electrostatic interactions, but not the YGNGV consensus motif, govern the binding of pediocin PA-1 and its fragments to phospholipid vesicles. Appl Environ Microbiol 63, 4770-4777.

Chikindas, M. L., Venema, K., Ledeboer, A. M., Venema, G. \& Kok, J. (1995). Expression of lactococcin A and pediocin PA-1 in heterologous hosts. Lett Appl Microbiol 21, 183-189.

Collins, M. D., Williams, A. M. \& Wallbanks, S. (1990). The phylogeny of Aerococcus and Pediococcus as determined by $16 \mathrm{~S}$ rRNA sequence analysis: description of Tetragenococcus gen. nov. FEMS Microbiol Lett 70, 255-262.

Daba, H., Pandian, H. D. S., Gosselin, J. F., Simard, R. E., Huang, J. \& Lacroix, C. (1991). Detection and activity of a bacteriocin produced by Leuconostoc mesenteroides. Appl Environ Microbiol 57, 3450-3455.

Dellaglio, F., Trovatelli, L. D. \& Sarra, P. G. (1981). DNA-DNA homology among representative strains of the genus Pediococcus. Zbl Bakt Hyg Abt Orig C2, 140-150.

Eldar, A., Goria, M., Ghittino, C., Zlotkin, A. \& Bercovier, H. (1999). Biodiversity of Lactobacillus garvieae strains isolated from fish in Europe, Asia and Australia. Appl Environ Microbiol 65, 1005-1008.

Fimland, G., Blingsmo, O. R., Sletten, K., Jung, G., Nes, I. \& NissenMeyer, J. (1996). New biologically active hybrid bacteriocins constructed by combining regions from various pediocin-like bacteriocins: the C-terminal region is important for determining specificity. Appl Environ Microbiol 62, 3313-3318.

Garmyn, D., Ferain, T., Bernard, N., Hols, P., Delplace, B. \& Delcour, J. (1995a). Pediococcus acidilactici ldhD gene: cloning, 
nucleotide sequence, and transcriptional analysis. J Bacteriol 177, 3427-3437.

Garmyn, D., Ferain, T., Bernard, N., Hols, P. \& Delcour, J. (1995b). Cloning, nucleotide sequence, and transcriptional analysis of the Pediococcus acidilactici L-(+)-lactate dehydrogenase gene. Appl Environ Microbiol 61, 266-272.

Garvie, E. I. (1986). Genus Pediococcus. In Bergey's Manual of Systematic Bacteriology, vol. 2, p. 1075. Edited by P. H. A. Sneath, N.S. Mair, M. E. Sharpe \& J. G. Holt. Baltimore: Williams \& Wilkins.

Groisillier, A. \& Lonvaud-Funel, A. (1999). Comparison of partial malolactic enzyme gene sequences for phylogenetic analysis of some lactic acid bacteria species and relationships with the malic enzyme. Int J Syst Bacteriol 49, 1417-1428.

Horn, N., Martínez, M. I., Hernández, P. E., Gasson, M. J., Rodríguez, J. M. \& Dodd, H. M. (1998). Production of pediocin PA-1 by Lactococcus lactis using the lactococcin A secretory apparatus. Appl Environ Microbiol 64, 818-823.

Lane, D. J. (1991). 16S/23S rRNA sequencing. In Nucleic Acid Techniques in Bacterial Systematics, pp. 115-175. Edited by E. Stackebrandt \& M. Goodfellow. Chichester: Wiley.

Leisner, J. J., Pot, B., Christensen, H., Rusul, G., Olsen, J. E., Wee, B. W., Muhamad, K. \& Ghazali, H. M. (1999). Identification of lactic acid bacteria from chili bo, a Malaysian food ingredient. Appl Environ Microbiol 65, 599-605.

Luchansky, J. B., Glass, K. A., Harsono, K. D \& 8 other authors (1992). Genomic analysis of Pediococcus starter cultures used to control Listeria monocytogenes in turkey summer sausage. Appl Environ Microbiol 58, 3053-3059.

Maiden, M. C. J., Bygraves, J. A., Feil, E. \& 10 other authors (1998). Multilocus sequence typing: a portable approach to the identification of clones within populations of pathogenic microorganisms. Proc Natl Acad Sci USA 95, 3140-3145.

de Mann, J. C., Rogosa, M. \& Sharpe, M. E. (1960). A medium for the cultivation of lactobacilli. J Appl Bacteriol 23, 130-135.

Marugg, J. D., Gonzalez, C. F., Kunka, B. S., Lebeboer, A. M., Pucci, M. J., Toonen, M. Y., Walker, S. A., Zoetmudler, L. C. M. \& Vanderbergh, P. A. (1992). Cloning, expression, and nucleotide sequence of genes involved in the production of pediocin PA-1, a bacteriocin from Pediococcus acidilactici PAC1.0. Appl Environ Microbiol 58, 2360-2367.

Miller, K. W., Schamber, R., Osmanagaoglu, O. \& Ray, B. (1998). Isolation and characterization of pediocin $\mathrm{AcH}$ chimeric protein mutants with altered bactericidal activity. Appl Environ Microbiol 64, 1997-2005.

Mora, D., Fortina, M. G., Parini, C. \& Manachini, P. L. (1997). Identification of Pediococcus acidilactici and Pediococcus pentosaceus based on $16 \mathrm{~S}$ rRNA and $l d h D$ gene-targeted multiplex PCR analysis. FEMS Microbiol Lett 151, 231-236.

Mora, D., Parini, C., Fortina, M. G. \& Manachini, P. L. (1998). Discrimination among pediocin $\mathrm{AcH} / \mathrm{PA}-1$ producer strains by comparison of pedB and pedD amplified genes and by multiplex PCR assay. Syst Appl Microbiol 21, 454-460.

Morse, R., Collins, M. D., Balsdon, J. T., Wallbanks, S. \& Richardson, P. T. (1996). Nucleotide sequence of part of the $r p o C$ gene encoding the $\beta^{\prime}$ subunit of DNA-dependent RNA polymerase from some Gram-positive bacteria and comparative amino acids sequence analysis. Syst Appl Microbiol 19, 150-157.

Motlagh, A. M., Holla, S., Johnson, M. C., Ray, B. \& Field, R. A. (1992). Inhibition of Listeria spp. in sterile food system by pediocin $\mathrm{AcH}$, a bacteriocin produced by Pediococcus acidilactici H. J Food Prot 55, 337-343.

Motlagh, A., Bukhtiyarova, M. \& Ray, B. (1994). Complete nucleotide sequence of pSMB74, a plasmid encoding the production of pediocin AcH in Pediococcus acidilactici. Lett Appl Microbiol 18, 305-312.

Nakagawa, A. \& Kitahara, K. (1959). Taxonomic studies on the genus Pediococcus. J Gen Appl Microbiol 5, 95-126.

Okereke, A. \& Montville, T. J. (1991). Bacteriocin inhibition of Clostridium botulinum spores by lactic acid bacteria. J Food Prot 1, 349-353.

Palys, T., Nakamura, L. K. \& Cohan, F. M. (1997). Discovery and classification of ecological diversity in the bacterial world: the role of DNA sequence data. Int J Syst Bacteriol 47, 1145-1156.

Pearson, W. R. (1990). Rapid and sensitive sequence comparison with FASTP and FASTA. Methods Enzymol 183, 63-98.

Pearson, W. R. \& Lipman, D. J. (1988). Improved tools for biological sequence analysis. Proc Natl Acad Sci USA 85, 2444-2448.

Pucci, M. J., Vedamuthu, E. R., Kunka, B. S. \& Vandenbergh, P. A. (1988). Inhibition of Listeria monocytogenes by using bacteriocin PA-1 produced by Pediococcus acidilactici PAC1.0. Appl Environ Microbiol 54, 2349-2353.

Ray, B. (1996). Characteristics and applications of pediocin(s) of Pediococcus acidilactici: pediocin PA-1/AcH. In Lactic Acid Bacteria: Current Advances in Metabolism, Genetics and Applications, pp. 155-203. Edited by T. F. Bozoglu \& B. Ray. Berlin \& Heidelberg: Springer.

Rohlf, F. J. (1987). NTSYS-PC: numerical taxonomy and multivariate analysis system for IBM PC microcomputer (and compatibles), version 1.30. New York: Applied Biostatistics.

Sambrook, J., Fritsch, E. F. \& Maniatis, T. (1989). Molecular Cloning: a Laboratory Manual, 2nd edn. Cold Spring Harbor, NY : Cold Spring Harbor Laboratory.

Schoeman, H., Vivier, M. A., Du Toit, M., Dicks, L. M. T. \& Pretorius, I. S. (1999). The development of bactericidal yeast strains by expressing the Pediococcus acidilactici pediocin gene (pedA) in Saccharomyces cerevisiae. Yeast 15, 647-656.

Sharpe, E. (1962). Taxonomy of the lactobacilli. Dairy Sci Abstr 24, 109-118.

Sneath, P. H. A. \& Sokal, R. R. (1973). Numerical Taxonomy: the Principles and Practice of Numerical Classification. San Francisco: W. H. Freeman.

Stiles, M. E. (1996). Biopreservation by lactic acid bacteria. Antonie Leeuwenhoek 70, 331-345.

Urbach, E., Daniels, B., Salama, M. S., Sandine, W. E. \& Giovannoni, S. T. (1997). The $l d h$ phylogeny for environmental isolates of Lactococcus lactis is consistent with rRNA genotypes but not with phenotypes. Appl Environ Microbiol 63, 694-702.

Venema, K., Kok, J., Marugg, J. D., Toonen, M. Y., Ledeboer, A. M., Venema, G. \& Chikindas, M. L. (1995). Functional analysis of the pediocin operon of Pediococcus acidilactici PAC1.0: PedB is the immunity protein and PedD is the precursor processing enzyme. Mol Microbiol 17, 515-522.

Welsh, J. \& McClelland, M. (1990). Fingerprinting genomes using PCR with arbitrary primers. Nucleic Acids Res 18, 7213-7218.

Received 25 January 2000; revised 11 April 2000; accepted 8 May 2000 